\title{
Analisa Perbandingan Model PJBL Dengan Model TCL Menggunakan PLC ZELIO pada Instalasi Motor Listrik Kelas XII di SMK VOCTECH 1 Kota Tangerang
}

Anna Safitri

Universitas Sultan Ageng Tirtayasa

anna.safitri02@gmail.com

Didik Aribowo

Universitas Sultan Ageng Tirtayasa

d aribowo@untirta.ac.id

Mohammad Fatkhurrokhman

Universitas Sultan Ageng Tirtayasa

fatkhur0404@untirta.ac.id

\begin{tabular}{|c|c|}
\hline Article History: & $\begin{array}{l}\text { Received: Oct } 12^{\text {th }} 2019 \\
\text { Revised: Feb } 13^{\text {th }} 2020 \\
\text { Accepted: March } 30^{\text {th }} 2020\end{array}$ \\
\hline
\end{tabular}

\begin{abstract}
The success of learning requires the components that support it, one of which is a learning model. The right learning Model can help students easily understand learning materials. Research focus on learning differences in student outcomes from the use of two learning models, namely Project Based Learning (PJBL) and conventional models (lectures), and calculates the effectiveness of the PJBL model using PLC Learning Media in the electricity engineering program at SMK Voctech 1 Tangerang City. The research Model used in this study is quantitative with a pseudo-experimental research method with the type of Nonequivalent control group design. This research consists of several stages, namely the preparation stage, then the implementation stage of the research, and the completion stage of the research. The data analysis used in this research is Test $\mathrm{U}$ and test-T. Based on the research done, the results are: (1) There are different learning outcomes on TCL and PJBL, in the realm of cognitive $u=21,000$ and significance 0.000 . In the realm of psychomotor $t=11,802$ and significance 0.000 . (2) The effectiveness of the PJBL model in the cognitive realm with the average value of the student score is 0.6183 which belongs to the category "effective". Project-based learning models can make it easier for students to understand the material that teachers are delivering, whether in the cognitive sphere or in the realm of psychomotor, because students are faced with the problem of producing a project to be completed.
\end{abstract}

Keyword : PJBL, Quasi Eksperimen, PLC, Learning outcomes 


\section{PENDAHULUAN}

Pendidikan memiliki fungsi untuk mengembangkan potensi yang dimiliki peserta didik, untuk itu guru harus mempersiapkan segala hal mengenai pembelajaran yang akan dilaksanakan dengan baik dan terencana agar setelah diadakannya Kegiatan Belajar Mengajar (KBM) peserta didik diharapkan memiliki potensi dan kemampuan yang mempuni. (Hariyanto \& Suyono, 2012) berpendapat bahwa belajar adalah suatu aktivitas atau suatu proses untuk memperoleh pengetahuan, meningkatkan keterampilan, memperbaiki perilaku, sikap, dan mengkokohkan kepribadian KBM terdiri dari beberapa kegiatan-kegiatan yang biasa disebut dengan pembelajaran. Setiap kegiatan yang dilakukan dalam pembelajaran disebut dengan model pembalajaran, model pembelajaran sendiri digunakan sebagai pedoman dalam pelaksanaan pembelajaran. Dalam Pelatihan Implementasi Kurikulum 2013 SMK, berdasarkan Permendikbud No. 103 tahun 2014, kurikulum 2013 menggunakan 3 (tiga) model pembelajaran yang diharapkan dapat membentuk perilaku saintifik, perilaku social serta mengembangkan rasa keingintahuan. Ketiga model tersebut adalah: model Pembelajaran Berbasis Masalah (Problem Based Learning), model Pembelajaran Berbasis Projek (Project Based Learning, dan model Pembelajaran Melalui Penyingkapan/Penemuan (Discovery/Inquiry Learning). (Direktorat Pembinaan SMK, 2016). Dari ketiga model pembelajaran tersebut, penggunaan ketiganya haruslah memperhatikan dari KD dan materi pembelajarannya sehingga tujuan dari pembelajaran akan tersampaikan kepada peserta didik.

Dari hasil observasi dan wawancara dengan guru mata pelajaran Instalasi Motor Listrik (IML) di SMK Voctech 1 Kota Tangerang, didapatkan informasi sebagai berikut: (1) Dalam pelaksanaan pembelajaran pemrograman PLC (Programable Logic Control) peserta didik terlihat kurang aktif dalam mengikuti pembelajaran. Beberapa siswa saling mengobrol dan tidak memperhatikan guru ketika menerangkan sehingga tidak kondusif selama pelaksanaan pembelajaran; (2) Pembelajaran pemrograman PLC, masih berpusat pada guru (teacher centered) sebagai sumber belajar; (3) Penggunaan media pembelajaran berupa trainer PLC belum maksimal hanya berupa LED dan motor listrik AC; (4) Rata-rata nilai siswa pada mata pelajaran IML masih dibawah KKM: 75, dengan nilai rata-rata XII TITL 1: 59.

Pada penerapannya di SMK, model pembelajaran yang masih banyak digunakan disekolah-sekolah adalah model konvensional (ceramah). Model ini menitikberatkan pada guru (teacher centered) sebagai sumber belajar, guru ceramah didepan kelas dan menulisnya di papan tulis sedangkan siswa mendengarkan dan menulis apa yang ada di papan tulis. Dalam pembelajaran seperti ini termasuk kedalam komunikasi satu arah sehingga siswa hanya menerima tanpa berpikir dan menemukan jawabannya sendiri. Siswa nantinya menjadi tidak kreatif dan menjadi tidak bersemangat dalam mengikuti pembelajaran karena dinilai tidak kreatif dan monoton sehingga siswa tidak tertarik dengan pembelajaran. Jika dalam suatu pembelajaran siswa tidak tertarik maka akan berpengaruh pada minat dan hasil belajar siswa kedepannya. 
Pembelajaran menurut (Arends, 1997) "the term teaching model refers to a particular approach to instruction that includes its goals, syntax, environment, and management system". Pada proses pembelajaran mengacu pada pendekatan mencakup tujuan, sintaks, lingkungan, dan sistem manajemen. Untuk meningkatkan minat dan kreatifitas siswa, guru dituntut untuk mencari dan menggunakan model pembelajaran yang tepat dan sesuai dengan pembelajaran yang dilakukan dengan memperhatikan KD dan materi pembelajaran yang akan diajarkan kepada siswa. Guru tidak hanya mencatat dan menerangkan, tetapi harus membuat nyaman disekolah (Prawitasari, 2014). Dari ketiga model pembelajaran kurikulum 2013, Project Based Learning (PJBL) dapat digunakan untuk membuat siswa menjadi lebih aktif dan mandiri dalam mengeksplor pengetahuannya.

Project Based Learning (PJBL) atau model pembelajaran berbasis proyek merupakan model pembelajaran yang memberikan tugas kepada siswa. Siswa dituntut untuk mengamati, membaca, dan meneliti (Yamin, 2012). Model pembelajaran PJBL memberi kesempatan kepada guru untuk mengelola kegiatan belajar mengajar di kelas dengan melibatkan kerja projek sebagai media pembelajaran. PJBL didukung teori belajar konstruktivistik. Konstruktivistik adalah teori belajar yang bersandar pada ide bahwa siswa membangun pengetahuannya sendiri di dalam konteks pengalamannya sendiri.

Pada pembelajaran PJBL, siswa dihadapkan dengan suatu masalah yang terlebih dahulu dianalisis dan selajutnya adalah diterapkan ke dunia nyata sehingga dapat meningkatkan daya analisis dan kemandirian siswa. Pembelajaran PJBL mengajarkan siswa aktif mandiri dalam pembelajaran. Siswa mengerjakan tugas, memecahkan masalah bersama kelompoknya sehingga terjalin komunikasi antar teman (Fatchan, Lestari, \& Ruja, 2016).

Selain dari model pembelajaran, permasalahan yang muncul adalah penggunaan media pembelajaran yang masih kurang maksimal. Penggunaan media dalam pembelajaran juga berpengaruh dalam meningkatkan hasil belajar siswa. Penggunaan media dalam pembelajaran dapat memberikan gambaran yang nyata mengenai kerja suatu alat atau sistem, mengingat pembelajaran di SMK lebih banyak melaksanakan praktik untuk memiliki keterampilan yang baik. Dari hasil penelitian yang dilakukan oleh (Julaiha \& Zulmiyetri, 2019) menunjukkan bahwa kemampuan penjumlahan anak meningkat setelah penggunaan permainan ular tangga sebagai media pembelajaran dengan hasil yang didapat adalah 80\%. Berdasarkan penelitian yang dilakukan oleh (Effendi, Hastuti, \& Hijriani, 2017) didapatkan hasil adanya peningkatan hasil belajar siswa setelah digunakannya media pembelajaran trainer PLC (Programmable Logic Control) omron pada mata pelajaran Instalasi Motor Listrik (IML) dengan gainscore (perbandingan pre-test dan post-test) sebesar 0,407 dengan kriteria sedang.

Peneliti menyimpulkan bahwa untuk meningkatkan hasil belajar dan daya tarik siswa maka diperlukan media pembelajaran dan pemilihan model pembelajaran yang tepat untuk membantu peserta didik dalam memahami bagaimana pembelajaran 
pemrograman PLC dengan menarik. Peneliti memilih Project Based Learning (PJBL) dalam upaya untuk meningkatkan hasil belajar siswa.

Dapat dijelaskan tujuan penelitian yang ingin dicapai dalam penelitian adalah: (1) Mengetahui perbedaan hasil belajar siswa dari penggunaan dua model pembelajaran yaitu project based learning dan model konvensional dengan menggunakan trainer PLC zelio dalam pembelajaran instalasi motor listrik. (2) Mengukur tingkat efektifitas dalam pelaksanaan model pembelajaran PJBL dan TCL pada ranah kognitif dalam pembelajaran instalasi motor listrik di SMK Voctech 1 Kota Tangerang.

Keterbatasan dari penelitian ini adalah, hasil yang dilihat hanya meliputi aspek kognitif dan psikomotorik, mata pelajaran yang diteliti hanya Instalasi Motor Listrik, penelitian hanya berfokus pada siswa kelas XII TITL SMK Voctech 1 Kota Tangerang, penggunaan media yang digunakan hanya terfokus pada PLC tipe SR3B261BD.

\section{KAJIAN PUSTAKA}

\section{Project Based Learning}

PJBL merupakan model pembelajaran yang berorientasi pada masalah namun menghasilkan sebuah proyek yang akan dijadikan sebagai bahan evaluasi. Menurut (Sani, 2017) PJBL merupakan strategi belajar mengajar yang melibatkan siswa untuk menggerakan sebuah proyek yang bermanfaat untuk menyelesaikan permasalahan masyarakat atau lingkungan. (Thomas, 2000) menyatakan "PJBL projects are focused on questions or problems that "drive" students to encounter (and struggle with) the central concepts and principles of a discipline"

Berdasarkan pegertian yang disampaikan oleh ahli dapat disimpulkan bahwa PJBL merupakan model pembelajaran yang tidak hanya berpusat pada guru tetapi juga berpusat kepada murid sehingga dalam pembelajaran murid akan lebih aktif dan kreatif dalam mengikuti pembelajaran.

Beberapa keuntungan dari project based learning menurut (Sani, 2017) adalah: (1) Meningkatkan motivasi siswa untuk belajar dan mendorong mereka untuk melakukan pekerjaan penting; (2) Meningkatkan kemampuan siswa dalam menyelesaikan masalah; (3) Membuat siswa lebih aktif dalam menyelesaikan permasalahan yang kompleks; (4) Meningkatkan kemampuan siswa dalam bekerja sama; (5) Mendorong siswa mempraktikkan keterampilan berkomunikasi; (6) Meningkatkan keterampilan siswa dalam mengelola sumber daya; (7) Memberikan pengalaman kepada siswa dalam mengorganisasi proyek, mengalokasikan waktu, dan mengelola sumber daya seperti peralatan dan bahan untuk menyelesaikan tugas; (8) Memberikan kesempatan belajar bagi siswa untuk berkembang sesuai kondisi dunia nyata; (9) Melibatkan siswa untuk belajar mengumpulkan informasi dan merapatkan pengetahuan tersebut untuk menyelesaikan permasalahan di dunia nyata; (10) Membuat suasana belajar menjadi menyenangkan. 
Langkah-langkah pelaksanaan model pembelejaran dapat dilihat pada Gambar 1.

Gambar 1. Langkah-langkah Pelaksanaan PJBL

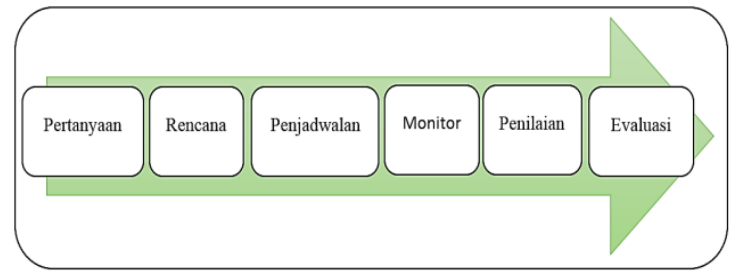

Sumber (Sani, 2017)

Berdasarkan data penelitian, model PJBL dapat peningkatan sikap ilSmiah siswa sekolah dasar menggunakan model PjBL secara signifikan lebih tinggi dibandingkan dengan model pembelajaran ekspositori dan dampaknya bagi mahluk hidup dan lingkungan (Alawiyah \& Supandi, 2015).

\section{Model Pembelajaran Konvensional}

Ceramah adalah penuturan atau penerangan secara lisan oleh guru terhadap kelas. Metode ceramah adalah metode yang boleh dikatakan metode tradisional karena sejak dulu metode ini telah dipergunakan sebagai alat komunikasi secara lisan antara guru dan anak didik dalam interaksi edukatif. (Jumanta: 2014)

Metode ceramah berbentuk penjelasan pengajar kepada siswa-siswa dan di akhiri dengan tanya jawab antara pengajar dan siswa tentang isi pelajaran yang kurang jelas oleh siswa. (Iskandar \& Mukhtar, 2011). Berdasarkan dari pengertian beberapa ahli, dapat disimpulkan bahwa metode ceramah adalah metode pembelajaran yang menitikberatkan pada guru dalam menyampaikan materi pembelajaran yang terdiri dari penjelasan secara lisan dan diakhiri dengan sesi tanya jawab yang dilakukan dari guru untuk mengetahui seberapa jauh pengetahuan yang telah disampaikan oleh guru terserap oleh siswa.

Kelebihan dari penggunaan metode ceramah adalah: (1) Guru mudah menguasai kelas karena guru menyampaikan informai dan materi secara langsung dengan tatap muka langsung dengan peserta didik; (2) Metode dianggap paling ekonomis waktu dan biaya karena waktu dan materi dapat diatur oleh guru secara langsung, materi dan waktu pelajaran sangat ditentukan oleh sistem nilai yang dimiliki oleh guru yang bersangkutan; (3) Mudah dilaksanakan; (4) Dapat diikuti anak didik dalam jumlah besar bisa juga dengan menggunakan media sound system sehingga suara guru yang menerangkan bisa terdengar lebih keras dengan jangkauan suara lebih jauh; (5) Guru mudah menerangkan bahan pelajaran berjumlah besar. 


\section{METODE}

Jenis penelitian ini adalah penelitian eksperimen. Menurut (Sugiyono, 2014), penelitian eksperimen adalah penelitian yang digunakan untuk mencari pengaruh perlakuan tertentu terhadap yang lain dalam kondisi yang terkendali.

Berdasarkan dari pengertian penelitian eksperimen diatas dapat disimpulkan bahwa penelitian eksperimen digunakan untuk mengetahui adanya hubungan sebab-akibat dari suatu variabel yang diteliti, apakah setelah adanya perlakuan yang diberikan kepada subyek penelitian berdampak atau tidak sehingga untuk mengetahui perbandingan adanya pengaruh atau tidaknya digunakan penilitian dengan model eksperimen.

Desain penelitian yang digunakan untuk penelitian adalah desain eksperimen semu (quasi-experimental designs). Perbedaan antara design eksperimen semu dan eksperimen sebenarnya adalah tidak adanya randomisasi dalam pemilihan subyek yang diteliti pada penelitian eksperimen.

Quasi eksperimen terbagi menjadi beberapa jenis, yaitu the nonequivalent control grup design, desain rangkaian waktu(the time-series design), dan desain berimbang (counterbalanced design). Jenis yang digunakan untuk pelaksanaan penelitian adalah jenis the nonequivalent control grup design, karena perbandingan antara kelas kontrol dan eksperimen terlihat jelas. Setiap kelas diberikan post-test dan juga pre-tes yang membedakannya adalah adanya perlakuan yang diberikan kepada kelas eksperimen sedangkan kelas kotrol tidak. Subyek diberikan dua kali pengukuran yaitu ketika awal pembelajaran (pre-test) utuk mengetahui kemampuan awal dari setiap siswadan kedua kalinya ketika akhir pembelajaran (post-test) untuk mengetahui adakah perbedaan antara sebelum dan sesudah diberikan perlakuan.

Desain pelaksanaan eksperimen semu dapat digambarkan pada Gambar 2.

\section{Gambar 2. Desain Eksperimen Semu Nonquivalent}

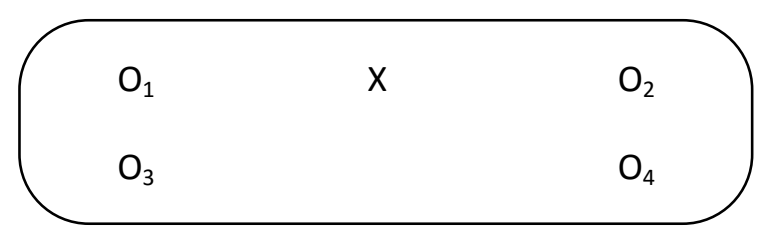

Dalam penelitian ini, peneliti membuat tahap-tahapan yang dilalui oleh peneliti adalah sebagai berikut:

a. Tahap Persiapan

1 Pembuatan rancangan penelitian;

2 Studi literatur;

3 Pembuatan instrumen;

4 Pembuatan media;

5 Proses validasi instrumen.

b. Tahap Pelaksanaan Penelitian

1 Menentukan kelas kontrol dan kelas eksperimen; 
2 Pelaksanaan pre-test pada kelas kontrol dan kelas ekperimen;

3 Pelaksanaan pembelajaran pada kelas kontrol dan eksperimen, pada kelas eksperimen adanya pemberian perlakuan khusus;

4 Pelaksanaan post-test pada kelas kontrol dan kelas eksperimen.

c. Tahap Penyelesaian Penelitian

1 Mengolah dan menganalisis data penelitian;

2 Pembahasan penelitian;

3 Penarikan kesimpulan penelitian;

4 Penyelesaian laporan penelitian

Penelitian ini dilakukan di SMK Voctech 1 Kota Tangerang dengan subjek kelas XII TITL 1 dan 2 tahun pelajaran 2019-2020.

Teknik pengumpulan data yang dilakukan dalam penelitian ini adalah dengan tes dan angket observasi. Teknik pengumpulan data dengga tes dilakukan untuk mengukur ranah kognitif sedangkan observasi dilakukan untuk mengambil data pada ranah psikomotor atau praktik. Tes dilakukan dengan memberikan 35 soal pilihan ganda pada kelas kontrol dan kelas eksperimen, dengan skor nilai benar adalah 1 dan salah adalah 0. Sebelum digunakan dalam penelitian, soal terlebih dahulu dilakukan pengujian validitas dan reliablitas untuk mengecek data yang digunakan valid dan reliabel untuk penelitian atau tidak. Jika soal yang digunakan valid dan reliabel maka dapat dilakukan untuk penelitian. Dari hasil perhitungan didapatkan hasil 35 soal valid dengan tingkat reliabilitas adalah 0,89 yang berarti bersifat reliabel.

Observasi dilakukan dengan mengamati hasil kerja siswa dalam hal praktik dan memberikan penilaian dengan skala 1-4 dilihat dari proses pengerjaan proyek dan hasil dari proyek yang dikerjakan.

Pada tahap pengolahan data dilakukan dengan 3 tahap, yaitu tahap uji prasyarat analisis, uji hipotesis, dan uji gain score. Pada tahap prasyarat analisis dibagi menjadi 2 macam perhitungan yaitu uji normalitas dan uji homogenitas.

Uji normalitas dilakukan untuk mengetahui apakah data yang didapatkan dari penelitian berdistribusi normal atau tidak. Uji homogenitas digunakan untuk mengetahui apakah data penelitian yang didapatkan bersifat homogen atau tidak. Uji hipotesis digunakan untuk menguji apakah hipotesis pada penelitian ini diterima atau tidak dengan menggunakan uji t test. Tahap terakhir adalah menguji nilai gain score dari penggunaan model pembelajaran PJBL, apakah masuk kedalam kategori rendah, sedang, dan tinggi. 


\section{HASIL DAN DISKUSI}

Dari penelitian kuantitatif dengan quasi eksperimen yang dilaksanakan di SMK Voctech 1 Kota Tangerang, dibagi menjadi 2 bagian yaitu data kelas eksperimen kelas XII TITL 1 dan data kelas kontrol kelas XII TITL 2. Dari data kelas kontrol dan eksperimen dibagi menjadi 2 aspek nilai, yaitu aspek kognitif dan aspek psikomotor. Penilaian aspek kognitif dilakukan dengan pre-test dan post-test sedangkan aspek psikomotor dilakukan dengan observasi penilaian siswa.

\section{Pelaksanaan Pre-Test}

Tahapan pertama dalam pelaksanaan penelitian adalah pelaksanaan pre-test terlebih dahulu. Pre-test dilakukan sebelum adanya perlakuan terhadap siswa. Pre-test tersebut berfungsi untuk mengukur sampai sejauh mana pemahaman siswa mengenai PLC. Dari hasil pre-test pada kelas kontrol dan kelas eksperimen didapatkan hasil pada Tabel 1.

Tabel 1. Data Deskriptif Hasil Pre-Test Kelas Kontrol dan Eksperimen

\begin{tabular}{|l|l|l|}
\hline Keterangan & \multicolumn{1}{|c|}{$\begin{array}{c}\text { Kelas } \\
\text { Kontrol }\end{array}$} & $\begin{array}{c}\text { Kelas } \\
\text { Eksperimen }\end{array}$ \\
\hline Jumlah siswa & 25 & 23 \\
\hline Mean & 39,24 & 35,22 \\
\hline Minimum & 26 & 17 \\
\hline Maximum & 54 & 51 \\
\hline
\end{tabular}

Berdasarkan data nilai pre-test kelas kontrol dan kelas eksperimen dapat diambil kesimpulan bahwa nilai rata-rata kelas kontrol lebih unggul dibandingkan nilai ratarata kelas eksperimen dengan perbedaan nilai meannya sebesar 4,02. Pada Gambar 4, dapat dilihat grafik perbedaan hasil pre-test siswa pada kelas kontrol dan kelas eksperimen.

Gambar 3. Grafik Perbedaan Nilai Rata-rata Pre-Test Kontrol dan Eksperimen

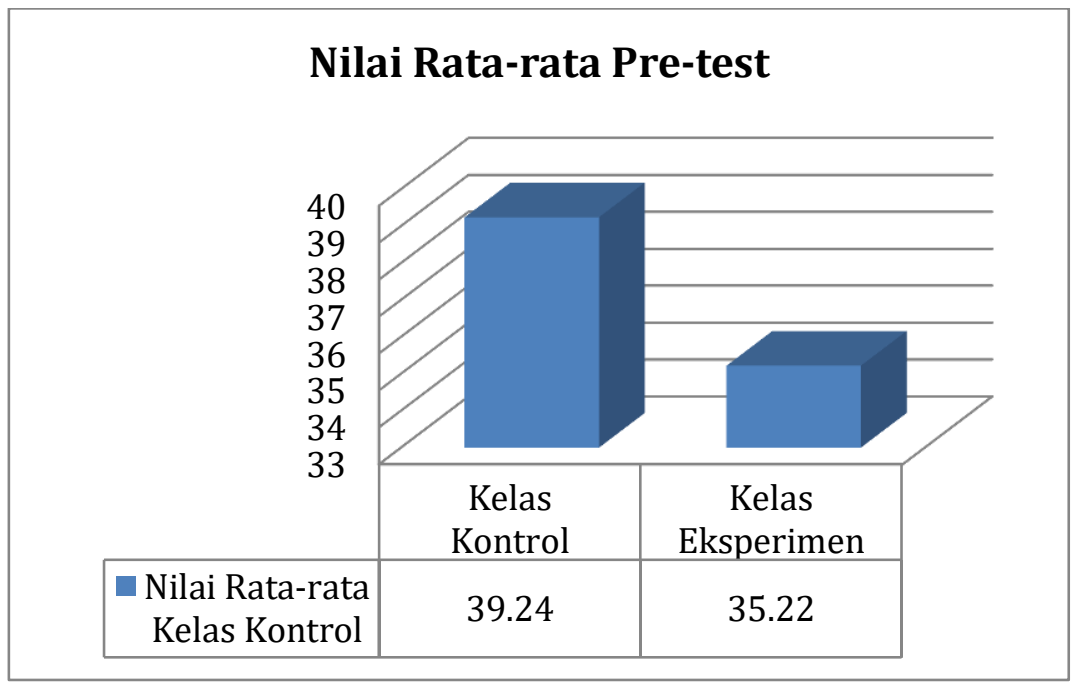




\section{Pelaksanaan Model PJBL dan Model TCL}

Setelah dilakukannya pre-test pada kelas kontrol dan kelas eksperimen, maka tahap selanjutnya adalah pelaksanaan perlakuan pada kedua kelas. Pada kelas kontrol diberikan model pembelajaran menggunakan model TCL, pada kelas eksperimen menggunakan model PJBL sehingga perlakuan pada setiap kelas berbeda. Perbedaan perlakuan tersebut yang menyebabkan hasil belajar pada kelas eksperimen dan kelas kontrol akan berbeda.

Pada setiap model pembelajaran, terhadap tahapan-tahapan perlakuan yang berbeda. Kelas kontrol memiliki 3 tahapan yang harus dilakukan yaitu: (1) pembuka, (2) penyajian, (3) penutup. Pada tahap pembukaan guru menjelaskan mengenai materi awal atau garis besar mengenai materi yang akan disampaikan. Tahapan penyajian adalah penyampaian materi pembelajaran kepada siswa dikelas. Dan tahap terakhir adalah penutup, pada tahap ini guru melaksanakan evaluasi pada materi pembelajaran yang diajarkan. Pada Gambar 5, dapat dilihat pelaksanaan proses pembelajaran pada kelas kontrol.

Kelas eksperimen memiliki 6 tahapan yang dilakukan, yaitu: (1) pertanyaan, (2) perencanaan, (3) penjadwalan, (4) monitor, (5) penilaian, dan (6) evaluasi.

Pada tahapan pertanyaan, guru membangun rasa ingin tahu siswa dengan memberikan persoalan mengenai pembelajaran instalasi motor listrik seperti menanyakan "bagaimana cara pemasangan lampu AC dengan kontrol pada saklar PB 1?". Pertanyaan tersebut dapat membuat siswa lebih antusias karna masih berkaitan dengan kegiatan sehari-hari. Setelah memberikan pertanyaan kepada siswa, maka guru akan mengarahkan siswa untuk membuat perencanaan dari pertanyaan yang sudah diberikan. Pada tahap ini guru membagi siswa kedalam beberapa kelompok belajar. Ketika sudah terbentuk kelompok belajar, siswa harus memperlajari bagaimana pembuatan program dan membaca diagram pengawatan untuk merangkai lampu AC dan PB 1 agar tehubung menggunakan PLC. Tahap penjadwalan adalah tahap untuk menentukan durasi pengerjaan proyek pada setiap kelompok. Pada tahap ini siswa dilatih rasa tanggung jawab dan mandiri terhadapat proyek yang dikerjakan. Monitoring atau tahap monitor, adalah tahap dimana guru memperhatikan siswa pada saat membuat program dan merangkai trainer PLC. Setelah siswa merangkai dilakukan penilaian. Tahap penilaian adalah tahap dimana guru menilai hasil pekerjaan siswa setelah membuat program dan merangkai. Pada tahap ini yang menjadi penilaian guru adalah dari penguasaan materi seperti membedakan input dan output, penerapan K3, dan hasil dari uji coba proyek. Tahap terakhir adalah tahap evaluasi. Tahap evaluasi bertujuan untuk mereview hasil dari pengerjaan proyek setiap kelompok

\section{Pelaksanaan Pre-Test}

Setelah pelaksanaan post-test dan perlakuan, tahap terakhir adalah pelaksanaan posttest atau penilaian akhir. Post-test dilakukan pada kelas kontrol dan kelas eksperimen dengan menggunakan 35 soal pilihan ganda. Selain pelaksanaan post-test, dilakukan 
juga penilaian psikomotor baik itu pada kelas kontrol maupun kelas eksperimen. Hasil penilaian post-test pada kelas kontrol dan kelas eksperimen dapat dilihat pada Tabel 2 .

Tabel 2. Data Deskriptif Hasil Perhitungan Post-Test pada Kelas Kontrol dan Kelas Eksperimen

\begin{tabular}{|l|l|l|}
\hline Keterangan & \multicolumn{1}{|c|}{$\begin{array}{c}\text { Kelas } \\
\text { Kontrol }\end{array}$} & $\begin{array}{c}\text { Kelas } \\
\text { Eksperimen }\end{array}$ \\
\hline Jumlah siswa & 25 & 23 \\
\hline Mean & 55,2 & 75,43 \\
\hline Minimum & 46 & 60 \\
\hline Maximum & 71 & 91 \\
\hline
\end{tabular}

Berdasarkan data nilai post-test kelas kontrol dan kelas eksperimen dapat diambil kesimpulan bahwa nilai rata-rata kelas eksperimen lebih unggul dibandingkan nilai rata-rata kelas kontrol dengan perbedaan nilai meannya sebesar 20,23. Pada Gambar 7 , dapat dilihat grafik perbedaan hasil post-test siswa pada kelas kontrol dan kelas eksperimen.

Gambar 4. Grafik Perbedaan Post-Test Kontrol dan Eksperimen

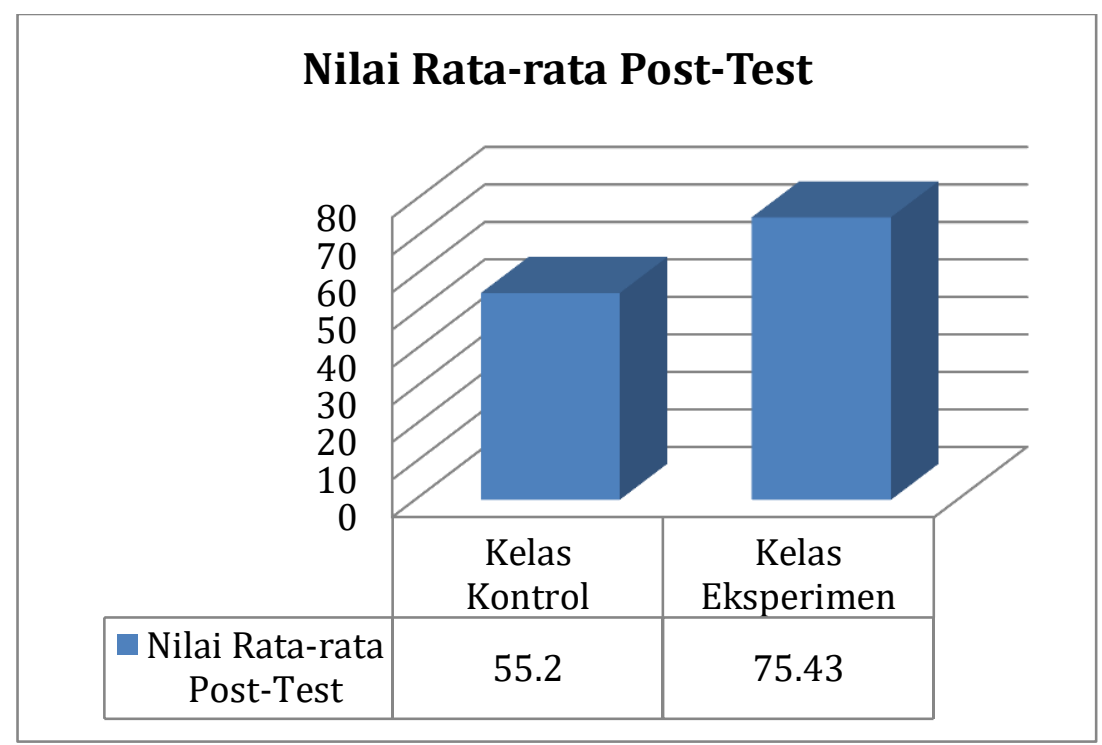

Dari hasil pengolahan data nilai post-test kelas kontrol dan kelas eksperimen, dapat dilakukan perhitungan uji $\mathrm{t}$ yang digunakan untuk mengetahui apakah terdapat perbedaan pada hasil belajar siswa ranah kognitif. Pada penelitian yang dilakukan oleh (Ramadhany, Purnomo, \& Suryadi, 2016) (Julaiha \& Zulmiyetri, 2019)dari hasil post-test yang dilakukan pada kelas PJBL didapatkan nilai terendah kelas adalah 70,00 dan nilai tertingginya adalah 93,33 dengan rata-rata kelas adalah 82,90. Pengaruh penggunaan model pembelajaran PJBL adalah 23,8\%.

Hasil yang didapat dari perhitungan uji t pada ranah kognitif terdapat pada Tabel 3. 
Tabel 3. Hasil Perhitungan Uji U Ranah Kognitif

\begin{tabular}{|l|r|}
\hline \multicolumn{2}{|c|}{ Test Statistics $^{\text {a }}$} \\
\hline & $\begin{array}{c}\text { Hasil Belajar } \\
\text { Siswa }\end{array}$ \\
\hline Mann-Whitney U & 21,000 \\
\hline Wilcoxon W & 346,000 \\
\hline$Z$ & $-5,516$ \\
\hline $\begin{array}{l}\text { Asymp. Sig. (2- } \\
\text { tailed) }\end{array}$ \\
\hline
\end{tabular}

Berdasarkan tabel tersebut dapat dilihat bahwa nilai sig, 2 tailed pada uji tersebut sebesar o,ooo yang menandakan bahwa terdapat perbedaan hasil belajar siswa pada ranah kognitif antara kelas kontrol dan kelas eksperimen dengan nilai U sebesar 21,000 .

Pelaksanaan penilaian psikomotor dilakukan dengan memberikan siswa proyek yang harus dikerjakan oleh siswa mengenai pengerjaan dengan menggunakan PLC zelio.Hasil yang didapat dari perhitungan olah data dengen menggunakan uji t test pada ranah psikomotor kelas kontrol dan kelas eksperimen terdapat pada Tabel 4.

Tabel 4. Hasil Perhitungan Uji T Ranah Psikomotor

\begin{tabular}{|c|c|c|c|c|c|}
\hline & \multicolumn{4}{|c|}{ t-test for Equality of Means } \\
\hline & & $t$ & $\begin{array}{l}\text { Sig. } \\
(2- \\
\text { taile } \\
\text { d) }\end{array}$ & $\begin{array}{c}\text { Mean } \\
\text { Differe } \\
\text { nce }\end{array}$ & $\begin{array}{l}\text { Std. } \\
\text { Error } \\
\text { Differ } \\
\text { ence }\end{array}$ \\
\hline $\begin{array}{l}\text { Test } \\
\text { Psik } \\
0\end{array}$ & $\begin{array}{l}\text { Equal } \\
\text { varianc } \\
\text { es } \\
\text { assum } \\
\text { ed }\end{array}$ & $\begin{array}{r}11,80 \\
2\end{array}$ & ,000 & 13,600 & 1,152 \\
\hline & $\begin{array}{l}\text { Equal } \\
\text { varianc } \\
\text { es not } \\
\text { assum } \\
\text { ed }\end{array}$ & $\begin{array}{r}11,80 \\
2\end{array}$ & ,000 & 13,600 & 1,152 \\
\hline
\end{tabular}

Berdasarkan tabel tersebut dapat dilihat bahwa nilai sig, 2 tailed pada uji tersebut sebesar o,ooo yang menandakan bahwa terdapat perbedaan hasil belajar siswa pada ranah psikomotor antara kelas kontrol dan kelas eksperimen dengan nilai $\mathrm{T}$ sebesar 11,802 . 
Dari hasil perhitungan menggunakan uji t test, dapat menjawab tujuan pertama penelitian yaitu apakah adanya perbedaan hasil belajar siswa. Jawaban dari pertanyaan tersebut adalah terdapat perbedaan hasil belajar siswa baik itu dari ranah kognitif maupun ranah psikomotor.

Setelah diketahui adanya perbedaan hasil belajar siswa pada ranah kognitif, selanjutnya adalah perhitungan nilai gain. Pada penelitian yang dilakukan oleh (Dwi Pudi, 2016) nilai gain score pada kelas eksperimen yang menggunakan model PJBL adalah 55,83 (Fatchan, Lestari, \& Ruja, 2016).

Setelah diketahui adanya perbedaan hasil belajar siswa pada ranah kognitif, selanjutnya adalah perhitungan nilai gain

Tabel 5. Kriteria Nilai Gain Score

\begin{tabular}{|l|l|}
\hline \multicolumn{1}{|c|}{ Kriteria } & \multicolumn{1}{c|}{ Kategori } \\
\hline $\mathrm{g}>0,7$ & Tinggi \\
\hline $0,7<\mathrm{g}>0,3$ & Sedang \\
\hline $\mathrm{g}<0,3$ & Rendah \\
\hline
\end{tabular}

Sumber (Hake, 1999)

Perhitungan gain score dilakukan dengan bantuan aplikasi SPSS. Hasil perhitungan gain score dapat dilihat pada Tabel 6.

Tabel 6. Hasil Perhitungan Nilai Gain score Model PJBL Kelas Eksperimen

\begin{tabular}{|l|l|r|r|r|r|}
\hline \multicolumn{7}{|c|}{ Group Statistics } \\
\hline & & & & $\begin{array}{c}\text { Std. } \\
\text { Devia }\end{array}$ & $\begin{array}{c}\text { Std. } \\
\text { Error } \\
\end{array}$ \\
& Kelas & N & an & tion & Mean \\
\hline NGain_- & Eksperi & 2 &, 61 &, 1199 &, 0250 \\
Score & men & 3 & 83 & 7 & 1 \\
\hline
\end{tabular}

Dari perhitungan gain score didapatkan hasil nilai rata-rata gain score adalah 0,6183 yang termasuk kedalam kategori "sedang".

Dari hasil perhitungan menggunakan uji gain score dapat menjawab tujuan kedua penelitian, yaitu seberapa efektifkah penggunaan model pembelajaran PJBL untuk meningkatkan hasil belajar siswa pada ranah kognitif. Jawaban dari pertanyaan tersebut adalah penggunaan model pembelajaran PJBL dapat meningkatkan hasil belajar siswa pada ranah kognitif dengan rata-rata nilai gain score sebesar 0,62 dengan kategori "sedang". 


\section{KESIMPULAN}

Berdasarkan penelitian yang dilakukan dapat ditarik kesimpulan sebagai jawaban dari tujuan penelitian yaitu, terdapat perbedaan capaian hasil belajar siswa antara kelas kontrol yang menggunakan model TCL dan kelas eksperimen yang menggunakan PJBL setalah adanya perlakuan. Setelah pengolahan data didapatkan hasil bahwa terdapat perbedaan pada ranah kognitif yaitu sebesar 20,235 dengan $U_{\text {hitung }}$ sebesar 21,000. Pada kelas eksperimen didapatkan nilai rata-rata skor kelas adalah 75,43 dan rata-rata skor kelas kontrol adalah 55,20. Berdasarkan nilai rata-rata siswa dan pengolahan nilai

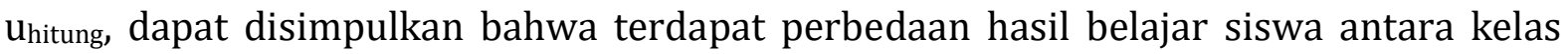
kontrol dan kelas eksperimen. Kelas eksperimen mengalami peningkatan hasil belajar pada ranah kognitif yang lebih tinggi dibandingkan dengan kelas kontrol.

Pada ranah psikomotor, terdapat perbedaan capaian hasil belajar siswa antara kelas kontrol yang menggunakan model TCL dan kelas eksperimen yang menggunakan model PJBL setelah adanya perlakuan. Setelah pengolahan data didapatkan hasil bahwa terdapat perbedaan hasil belajar pada ranah psikomotor yaitu sebesar 13,6 dengan $t$ hitung sebesar 11,802 dan $\mathrm{t}$ tabel sebesar 2,485 atau dapat dikatakan bahwa $\mathrm{t}$ hitung $>\mathrm{t}$ tabel. Pada kelas eksperimen didapatkan skor rata-rata kelas adalah 39,96 dan rata-rata skor kelas kontrol adalah 24,64. Berdasarkan skor rata-rata siswa dan pengolahan nilai $t$ hitung, dapat disimpulkan bahwa terdapat perbedaan hasil belajar siswa antara kelas kontrol dan kelas eksperimen. Kelas eksperimen mengalami peningkatan hasil belajar pada ranah psikomotor yang lebih tinggi dibandingkan dengan kelas kontrol.

Pada penelitian ini, penggunaan model pembelajaran berbasis proyek dapat meningkatkan hasil belajar siswa pada ranah kognitif. Hal ini dibuktikan dengan ratarata nilai gain score siswa adalah 0,6183 yang termasuk dalam kategori "efektif".

\section{DAFTAR PUSTAKA}

Alawiyah, I., \& Supandi, W. (2015). Pembelajaran Berbasis Proyek Untuk Meningkatkan Sikap Ilmiah Siswa Sekolah Dasar Pada Materi Peristiwa Alam. Jurnal Penelitian LPPM Universitas Pendidikan Indonesia.

Arends, R. I. (1997). Classroom instruction management. New York: McGraw-Hill Companies.

Effendi, H., Hastuti, \& Hijriani, S. (2017). PENERAPAN TRAINER PLC OMRON SEBAGAI MEDIA PEMBELAJARAN MATA DIKLAT INSTALASI MOTOR LISTRIK. Invotek, 55.

Fatchan, A., Lestari, D. P., \& Ruja, I. N. (2016). PENGARUH MODEL PEMBELAJARAN PROJECT BASED LEARNING BERBASIS OUTDOOR STUDY TERHADAP HASIL BELAJAR GEOGRAFI SISWA SMA. Teori, Penelitian dan Pengembangan, 475-479.

Hake, R. R. (1999). Analyzing Change Gain.

Hariyanto, \& Suyono. (2012). Belajar dan Pembelajaran: Teori dan Konsep Dasar. Bandung: Remaja Rosdakarya. 
Iskandar, \& Mukhtar. (2011). Desain Pembelajaran Berbasis Teknologi Informasi dan Komunikasi. Jakarta: Gaung Persada.

Julaiha, M., \& Zulmiyetri. (2019). Effectivity of Snakes and Ladders Media to Upgrade to the Summation in Children Learning Difficulties. Edutec: Jurnal of education and technology, 54-61.

Prawitasari, F. (2014, Maret 6). Kurikulum 2013 Menekankan Perkembangan Karakter Anak. Diambil kembali Kari Kompas.com: https://edukasi.kompas.com/read/2014/03/06/1934280/Kurikulum.2013.Me nekankan.Pembangunan.Karakter.Anak

Ramadhany, A., Purnomo, A., \& Suryadi, A. (2016). Pengaruh Penggunaan Model Pembelajaran Project Based Learning pada Pembelajaran Sejarah Terhadap Hasil Belajar Siswa Kelas XI IPS MAN Temanggung. Indonesia Journal Of History Education, 14-20.

Sani, R. A. (2017). Pembelajaran Saintifik Untuk Implementasi Kurikulum 2013. Jakarta: Bumi Aksara.

Sugiyono. (2014). Metode Penelitian Kuantitatif, Kulitatif dan R\&D. Bandung: Alfabeta. Thomas, J. W. (2000). A Review Of Research Project Based Learning. The Autodesk Foundation.

Yamin, M. (2012). Desain Baru Pembelajaran Konstruktivistik. Jakarta: Raja Grafindo Persada. 